\title{
PREFACE
}

Senatorial confirmation of appointments by the President is essentially an American practice, virtually unknown in other major countries of the world, except countries in Central and South America which have patterned their constitutions after ours. In this country it exists not only in the national government but in the states and cities, where it has been copied from the federal Constitution. The actual operation in state and city governments, however, is quite different from that in the national government.

The requirement that the appointment of officers of the United States by the President shall be subject to the approval of the Senate is one of the important powers of that body and is a basic part of the division of powers between the President and the Congress. Heretofore this function of the Senate has been neglected by most political scientists; no definitive study has been made of its history, operation, and effects. A number of writers on government have criticized senatorial confirmation of appointments, particularly appointments to minor positions, on the ground that it serves to perpetuate patronage appointments; but no serious proposal has ever been made to alter this provision of the Constitution. Many sensational controversies have arisen between the Senate and the President over appointments, and it may be questioned whether the Senate's participation in the appointing power has in its actual operation borne out the confident expectations of the framers of the Constitution that it would serve as a salutary check on the President and provide a safeguard against unfit appointments.

I was led to undertake the study because of the series of bills and riders which were introduced in Congress practically every year from 1935 to 1945 to extend senatorial confirmation to many subordinate administrative positions. Several 


\section{Viii] PREFACE}

of these proposals were enacted into law, and most of them passed the Senate without opposition. They constituted one of the greatest threats to the federal civil service within recent years. Happily, similar bills have not been pushed in Congress lately, and the trend has been in the opposite direction. The issue, however, is a perennial one; it arose again in $195^{2}$ in the consideration of President Truman's reorganization plans, and it may be expected to recur in the future.

The purpose of this study is to trace the history of the confirmation of appointments by the Senate from the framing of the Constitution to the present and to analyze the practical operation and effects of the practice. In recent controversies over the roles of the President and the Senate with regard to appointments the constitutional issues have loomed large; for this reason special attention has been given to the debates over the appointing power in the Constitutional Convention of 1787 and to contemporary discussions of this section of the Constitution. What was the purpose of the framers of the Constitution in requiring the approval of the Senate to appointments? And has the actual experience conformed to the intentions of the founding fathers? What have been the practical operations and effects of senatorial confirmation? Has it provided a salutary safeguard against unwise and unfit appointments and the possibility of abuse of the appointing power if that power were vested in the President alone? Has it resulted in higher or in lower standards of qualifications of persons appointed as officers of the federal government? What effect has it had on patronage appointments? What are the various relationships between the President and the Senate in their joint exercise of the appointing power? What faults or weaknesses exist in the system, and what reforms or improvements should be made?

The central issue to which this study is directed is which officers should be appointed by the President and confirmed by the Senate and which should be appointed otherwise. The decision is an important one, for the method of appointment of subordinate officers vitally affects the administration of the government and the federal civil service. For certain classes of officers the requirement of senatorial confirmation of appointments has worked reasonably well and has provided, as the framers of the Constitution intended, a salutary safeguard against unfit appointments; for other classes it has worked badly, resulting in the perpetuation of partisan and patronage appointments to positions which belong in the career civil service; for still others, senatorial confirmation has become for the most part an empty formality of little practical significance. Three official commissions that surveyed the organization and administration of the federal government within the last forty years each made the identical recommendation that subordinate administrative officers in the executive departments and agencies be appointed by the responsible executive officers, normally from the civil service, instead of being appointed by the 


\section{PREFACE $\quad[\mathrm{ix}$}

President and the Senate. No action was taken to carry out these recommendations, however, until 1952, when President Truman, after a series of sensational scandals unearthed by congressional investigations of the internal revenue service, submitted to Congress four reorganization plans to place postmasters, collectors of internal revenue and customs, and marshals under the career civil service. Only one of the plans, that relating to collectors of internal revenue, went into effect; the others were rejected by the Senate.

A second major problem with which this study is concerned is the policies, procedures, and practices of the Senate in passing upon presidential nominations. These practices vary widely for different types of officers, and they have changed with the years. What tests does the Senate apply in passing on nominations? For what reasons have nominees been rejected? In which appointments should the President be permitted wide latitude of choice and his nominations be approved unless the nominee is definitely disqualified or unsuitable? For which offices should the Senate consider the President's nominations with care and reject nominees not only because of their disqualifications for the office but because their views are not agreeable to a majority of the Senate? Have the methods and procedures used by the Senate for inquiring into the qualifications of candidates been suitable? If not, in what ways should they be altered? Has the Senate secured adequate information to enable it intelligently to pass upon the nominations that come before it? Has the requirement of senatorial confirmation caused able men to decline federal appointment? Is the custom of "senatorial courtesy"-under which the Senate will reject a nomination because of the objections of a senator from the state in which the office is situated, or from the state in which the nominee residesjustified? What have been the effects of the custom?

These are some of the principal questions which this study attempts to answer. It is assumed that senatorial confirmation of appointments of the principal officers of the government is a basic part of the Constitution and is unlikely ever to be amended or repealed. The Senate will undoubtedly never consent to give up this important function, which is a part of the division of powers between the President and the Congress. But though the Constitution will in all probability remain unchanged, the classes of officers appointed by the President and confirmed by the Senate may change, and the practices of the Senate in passing upon appointments are also subject to modification.

I wish to express my gratitude to the University of California and the Committee on Public Administration of the Social Science Research Council for financial assistance that has greatly aided me in the conduct of the study. A large part of the study was made while I was on sabbatical leave of absence from the University in 1949 and 1950; during this period and the two following years I also received a special grant from the Institute of Social Sciences of the University of California. I am greatly indebted to many persons: members of 


\section{$\mathrm{X}$ ] PREFACE}

Congress, federal officials, members of the Washington press, and others with whom I have discussed specific cases and the general practices and effects of senatorial confirmation. The editors of the American Political Science Review and the Political Science Quarterly have kindly consented to the publication in this volume, in slightly revised form, of two articles which appeared earlier in these journals. Especial thanks are due the following persons who have read parts of the manuscript and whose criticisms and comments have been most helpful: Messrs. Louis Brownlow and Don K. Price, Professor Leonard D. White, and my colleagues, Professors Peter H. Odegard, Charles Aikin, Leslie Lipson, and Dwight C. Waldo.

I have been greatly aided by the able research assistance of Dr. Felix Nigro, Patricia Howse, and Edith Carper, who participated in the study at different periods; but I take sole responsibility for the findings and conclusions and for any errors in fact or in judgment that it may contain.

JOSEPH P. HARRIS

Berkeley, California

May 15,1953 